\title{
Criminal violence and displacement in Mexico
}

\section{Sebastián Albuja}

Rampant criminal violence, from direct coercion and physical threats to the erosion of the quality of life and livelihood opportunities, pushes people to move in a variety of ways. Not everyone forced to move has equal access to protection or asylum.

According to official Mexican government information, 47,000 people were killed as a result of the wave of intense criminal violence which started in 2007. Civil society estimates put the figure as high as 70,000 in April 2012. Displacement of civilians has been a significant effect of the drug war in Mexico.

Civil society organisations, academic institutions and the media have progressively begun to document cases and patterns of forced displacement caused by drug-cartel violence, seeking to untangle the different forms of human mobility and distinguish migration that is forced from migration that is not. Overall, the proportion of people leaving violent municipalities is four to five times higher than that of people leaving non-violent municipalities with similar socio-economic conditions. In addition to displacement of Mexicans, the safety of Central and South American migrants making their way to the US through Mexico has become greatly threatened as a result of increased insecurity and drug-cartel violence. It has been estimated that 70,000 Central and South American migrants have disappeared since 2007 while crossing through Mexico. ${ }^{1}$

This context begs the question: at what point does criminal violence give rise to a humanitarian crisis? The intensity and pervasiveness of the violence in Mexico certainly poses a widespread threat to life: between 50,000 and 70,000 people killed in a six-year period is by any measure an enormous loss of life. Furthermore, systematic and large-scale kidnapping of migrants as well as mass murders of migrants present a widespread threat to life and physical security and constitute a humanitarian crisis. Finally, the violence has also been associated with loss of livelihoods and subsistence, which pushes people to leave.

While violence and insecurity need not occur in the context of an internal armed conflict in order to constitute a humanitarian crisis, the existence of a conflict would reinforce the view that Mexico's situation of violence does amount to a humanitarian crisis. In fact a prima facie analysis of Mexico's violence under criteria established by IHL shows that the situation meets most of the criteria for the existence of a non-international armed conflict, despite the fact that Mexican drug cartels do not have a political agenda or an ideology.

\section{What protection do existing legal frameworks offer?}

Acts that violate criminal law (including robbery, assault, rape and murder) occur in every society and are predominantly dealt with through retributive justice 
focusing on punishment of offenders but they largely neglect crime's impact on victims. This neglect of victims, including those who migrate as a result of criminal violence, is significant in contexts of intense criminal violence such as Mexico's.

The existing international protection framework - the various universal, regional, binding and non-binding instruments of refugee law, IHL and human rights law - provides the desired emphasis on the rights, needs and vulnerabilities of victims, including those who move as a result of criminal violence or are affected by it. But the protection structure's focus on forced or coerced movement as the trigger does not adequately respond to the complex mobility circumstances of people in contexts of criminal violence.

The descriptive identification of people who may be IDPs in the Guiding Principles on Internal Displacement includes persons who flee "situations of generalized violence." The situation in certain localities in Mexico may be understood to be one of generalised violence. Under the Guiding Principles, there must be coercion for people to be considered IDPs. But in some situations, people move after their source of income has declined or become less sustainable as a result of the pervasive climate of violence and insecurity. For example, some people in Ciudad Juárez have moved because their small businesses became less profitable or threatened to fold when, due to violence and insecurity, people stopped shopping or eating in the neighbourhood where the businesses are located. In these cases, while people have not been directly coerced to move, their choice to move is not entirely free either.

\section{A broad interpretation of the Guiding}

Principles may provide relief to people in this situation. People who move seeking a source of income but who would have not chosen to move were it not for the negative impact of insecurity and violence on their livelihoods - in other words, they do not move solely to improve their economic circumstances as a free choice - would warrant protection as
IDPs on the grounds that they were forced to move because of the climate of insecurity.

People crossing borders seeking safety and security as a result of criminal violence, whether as a direct consequence of it or anticipating threats, are specifically covered by the expansive definition of a refugee in the 1984 Cartagena Declaration, which includes people who flee the threat posed by "generalized violence, ... massive violation of human rights or other circumstances which have seriously disturbed public order". ${ }^{2}$ Under the 1951 Refugee Convention protection is available on a case-by-case basis to those who can show a well-founded fear of persecution based on one of the five grounds enumerated in the Convention.

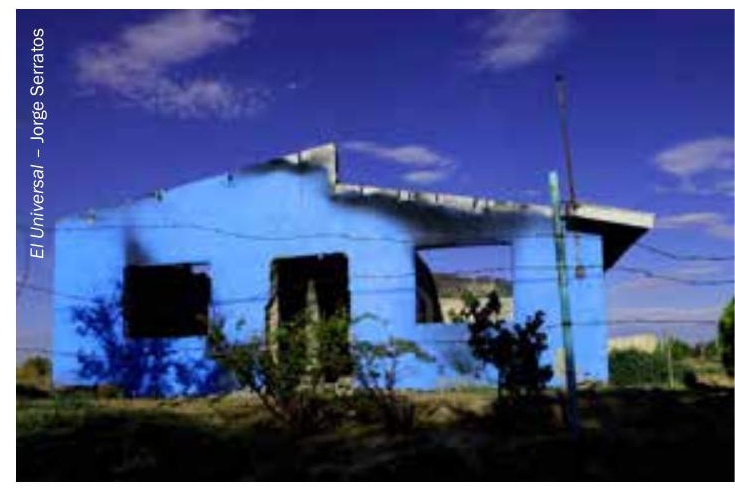

Homes abandoned by IDPs and vandalised by criminal groups in El Porvenir, Chihuahua, 2010.

Complementary protection may also offer relief to people who have fled criminal violence but the threshold above which it is applicable - under the Convention Against Torture (CAT), for example - makes this an even narrower avenue for protection. ${ }^{3}$ Asylum seekers could also benefit from complementary protection under the Convention for the Protection of All Persons from Enforced Disappearances, Article 16 of which prohibits the refoulement of individuals to a state where there is a risk of them being subjected to enforced disappearance. ${ }^{4}$

Regional human rights instruments also provide a potential avenue for protection. The 
European Qualification Directive provides for a similar prohibition from return in Article 2(e) on subsidiary protection. This article applies to third-country nationals and stateless persons who do not qualify as refugees but who are in need of international protection and who, if returned to their country of origin or residence, are at a risk of suffering "serious harm" i.e. death penalty or execution; torture or degrading treatment or punishment; or "serious and individual threat to a civilian's life or person by reason of indiscriminate violence in situations of international or internal armed conflict". The extent to which the situation in Mexico can be regarded as an internal armed conflict thus has an impact on the applicability of this form of relief.

\section{Protection inside Mexico and asylum in the US}

Response to internal displacement in Mexico itself has been limited predominantly because of a lack of will to acknowledge the issue and address it systematically. The Mexican government has yet to fully acknowledge that cartel violence is causing people to move (under coercion or not) and has not put in place any mechanisms to respond to displacement since the violence broke out.

Two exceptions are the Office for the Victims of Crime (Províctima), which was created by Presidential Decree in September 2011, with a mandate to assist people affected by kidnapping, forced disappearance, homicide, extortion and human trafficking, and the National Human Rights Commission which has, since 2011, taken the complaints of people displaced by violence, and is in the process of drafting a protocol to guide its attention to IDPs.

Although the Federal Government is powerful and professionalised, it may have little inclination to request support from foreign and multilateral humanitarian agencies, whose intervention is much needed the local level. Local governments in whose jurisdictions the violence takes place are resource-poor, plagued with corruption and co-opted by the very illegal groups they are supposed to fight. They are thus utterly unable to provide protection to the populations affected by the violence.

The response of US authorities to asylum claims linked to drug-cartel violence in Mexico serves as an example to examine the potential for protection that the refugee regime offers to people fleeing criminal violence across borders. The statistics of successful asylum claims by Mexicans seeking asylum as a result of drug-cartel violence, on the one hand, and the legal reasoning supporting court decisions, on the other, suggests that this avenue is limited as a form of protection.

The majority of 203 appeals cases analysed were rejected for failure to show a wellfounded fear of persecution. Petitioners - predominantly in cases of defensive asylum claims pending removal from the US - attempted unsuccessfully to argue that they were part of a social group persecuted by organised crime.

Cases that argued fear of generalised violence or unstable country conditions as the reason for fleeing and as grounds for asylum were rejected. Courts ruled that fear of "general country conditions" or "indiscriminate violence" was not ground for asylum, unless victims are singled out on account of a protected ground. The cases that were successful had specific evidence (names of cartel or police members, hospital or police reports, and witness testimony). They also could demonstrate and articulate why and how they feared persecution (i.e. who would harm them).

\section{Conclusions}

A hallmark feature of environments where criminal violence is rampant is that it pushes people to move in a variety of ways, from direct coercion and physical threats to the erosion of the general environment and quality of life, to shrinking livelihood opportunities. Criminal violence causes and affects human mobility in Mexico, creating - in its intensity and pervasiveness - a humanitarian crisis. Therefore there 
needs to be a fundamental shift in responses by concerned states and the international community, from punishing or defeating the offenders to giving full weight to the needs of victims, including migrants.

The existing international protection framework provides such a focus on the needs and vulnerabilities of people moving as a result of criminal violence. Through new interpretations of existing legal norms, people who do not clearly fall within the existing legal categories could potentially find protection. A broad interpretation of the Guiding Principles could include as IDPs people who flee without direct coercion but who do not move out of free choice either. Likewise, innovative interpretations of the grounds for asylum in the Refugee Convention could provide relief to people in these situations.

However, even if interpretation of existing frameworks may in principle offer protection, practical implementation remains the biggest challenge. In the absence of a state response for people displaced by violence in Mexico, humanitarian agencies should engage to protect people affected and displaced by violence. But situations of insecurity caused by criminal violence often fall outside the mandates and mission statements of humanitarian agencies; among the international agencies currently in Mexico, no agency has thus far set up programmes to respond to the impacts of criminal violence on local communities. And up to now, the Mexican government has not sought cooperation from international agencies in relation to drug-cartel violence; to do so would be to acknowledge that the country faces a humanitarian crisis or is in the grip of an armed conflict.

\section{Sebastián Albuja sebastian.albuja@nrc.ch is} Head of the Africa and Americas Department of the Norwegian Refugee Council's Internal Displacement Monitoring Centre. www.internal-displacement.org

1. Sherman, C Central American Mothers Look for Missing Migrants, Associated Press, 2012.

http://bigstory.ap.org/article/central-american-mothers-lookmissing-migrants.

2. www.refworld.org/docid/3ae6b36ec.html

3. www.hrweb.org/legal/cat.html The term torture, as defined in the CAT, contains a public requirement, which means that for an act to be counted as torture it has to be carried out by a public official or with their 'consent' or 'acquiescence'.

4. With particular reference to the situation of Mexican asylum seekers in the US, note that the US is not a State Party to the Convention for the Protection of All Persons from Enforced Disappearances. Convention online at www.ohchr.org/EN/HRBodies/CED/Pages/ConventionCED.aspx 